\title{
PARIWISATA MENJADI KEKUATAN BARU EKONOMI DI DESA WAWOANGI
}

Mahyudin ${ }^{1}$, Hamdan Hidayat ${ }^{2}$, Asril Midu ${ }^{3}$, Hasriana ${ }^{4}$

${ }^{1}$ Dosen Program Studi Ilmu Pemerintahan, Fakultas Ilmu Sosial dan Ilmu Politik

${ }^{234}$ Mahasiswa Program Studi Ilmu Pemerintahan, Fakultas Ilmu Sosial dan Ilmu Politik

Universitas Muhammadiyah Buton

Email: mahyuddinfaith2018@gmail.com

Submited : 1 Agustus 2020

Acepted : 12 Agustus 2020

Published : Desember 2020

\begin{abstract}
Abstrak
Kegiatan PKM ini diselenggarakan di Desa Wawoangi Kecamatan Sampolawa Kabupaten Buton Selatan. Masalah yang dihadapi mitra adalah Kurangnya wawasan dan kesadaran masyarakat lokal akan pentingnya pembangunan di bidang kepariwisataan. Tujuan dari PKM ini dilaksanakan ialah untuk memberikan pendampingan pembinaan pengelolaan pariwisata dan arahan pengembangan pariwisata. Program pengabdian masyarakat ini menyimpulkan bahwa peran modal sosial dapat digunakan untuk masyarakat dalam bentuk pengetahuan lokal, yang kemudian dapat dimanfaatkan sebagai sarana pendampingan, pembinaan, pengelolaan pariwisata dan arahan pengembangan objek wisata kepada pemerintah desa dan masayarakat Desa Wawoangi. Dengan dikelolanya objek wisata di Desa Wawoangi ini akan mendorong laju perekonomian rakyat, karena dengan adanya tujuan wisata di desa ini akan mampu mempromosikan semua sektor ekonomi yang ada di desa, baik itu dari kerajinan, pertanian, dan budaya.
\end{abstract}

Kata Kunci : Pariwisata, Ekonomi Desa 


\section{PENDAHULUAN}

Salah satu pendekatan pengembangan wisata alternatif adalah desa wisata untuk pembangunan pedesaan yang berkelanjutan dalam bidang pariwisata. Ramuan utama desa wisata diwujudkan dalam gaya hidup dan kualitas hidup masyarakatnya. Keaslian juga dipengaruhi keadaan ekonomi, fisik dan sosial daerah pedesaan tersebut, misalnya ruang, warisan budaya, kegiatan pertanian, bentangan alam, jasa, pariwisata sejarah dan budaya, serta pengalaman yang unik dan eksotis khas daerah. Dengan demikian, pemodelan desa wisata harus terus dan secara kreatif mengembangkan identitas atau ciri khas daerah.

Dalam hal pengelolaan Pendapatan, desa berhak mengelola dan menggali potensipotensi yang terdapat di desanya sehingga dapat meningkatkan Pendapatan Asli Desa (PADes). Salah satu potensi yang dapat ditingkatkan menjadi Pendapatan Asli Desa (PADes) adalah sektor pariwisata. Pengembangan sektor pariwisata sebagai salah satu bagian dari pengembangan sektor ekonomi kreatif saat ini menjadi salah satu program prioritas pembangunan pemerintah pusat (Listriyana \& Pahlewi, 2019).

Pariwisata adalah perjalanan dari satu tempat ke tempat lain bersifat sementara, dilakukan perorangan atau kelompok, sebagai usaha mencari keseimbangan dan kebahagiaan dengan lingkungan hidup dalam dimensi sosial, budaya, alam, dan ilmu (Sefira Ryalita Primadany, Mardiyono, 2013). Di luar faktorfaktor tersebut, alam dan lingkungan yang masih asli dan terjaga merupakan salah satu faktor terpenting dari sebuah kawasan tujuan wisata (Zakaria \& Suprihardjo, 2014).

Prinsip pengembangan desa wisata adalah sebagai salah satu produk wisata alternatif yang dapat memberikan dorongan bagi pembangunan pedesaan yang berkelanjutan serta memiliki prinsip-prinsip pengelolaan antara lain, ialah: (1) memanfaatkan sarana dan prasarana masyarakat setempat, (2) menguntungkan masyarakat setempat, (3) berskala kecil untuk memudahkan terjalinnya hubungan timbal balik dengan masyarakat setempat, (4) melibatkan masyarakat setempat, (5) menerapkan pengembangan produk wisata pedesaan, dan beberapa kriteria yang mendasarinya seperti antara lain: 1. penyediaan fasilitas dan prasarana yang dimiliki masyarakat lokal yang biasanya mendorong peran serta masyarakat dan menjamin adanya akses ke sumber fisik merupakan batu loncatan untuk berkembangnya desa wisata; 2. Mendorong peningkatan pendapatan dari sektor pertanian dan kegiatan ekonomi tradisional lainnya; 3 . Penduduk setempat memiliki peranan yang efektif dalam proses pembuatan keputusan tentang bentuk pariwisata yang memanfaatkan kawasan lingkungan dan penduduk setempat memperoleh pembagian pendapatan yang pantas dari kegiatan pariwisata; dan 4 . Mendorong perkembangan kewirausahaan masyarakat setempat (Out et al., 2010).

Salah satu desa yang juga memiliki potensi dikelola dan di kembangkan berdasarkan prinsip-prinsip pariwisata berkelanjutan, yaitu Desa Wawoangi yang terletak di Kecamatan 
Sampolawa Kabupaten Buton Selatan. Desa Wawowangi memiliki sumber daya alam yang potensial yaitu Wisata Pantai La poili, destinasi wisata jembatan lingkar yang berada diatas laut, indah dan pemandangan lautan lepas yang terlihat jelas.

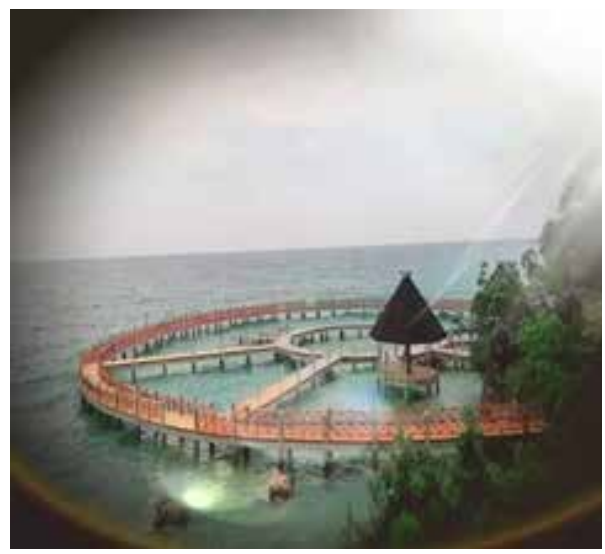

Gambar 1. Pantai Lapoili Wisata Jembatan Lingkar

Pantai La Poili merupakan destinasi wisata baru di Desa Wawoangi. Pantai ini dulunya hanyalah hamparan batu karang di bawah tebing, kini disulap menjadi pantai yang indah.

Selain jembatan linkar Desa Wawoangi memiliki objek wisata sejarah dan religi yaitu Masjid tua Wawoangi.

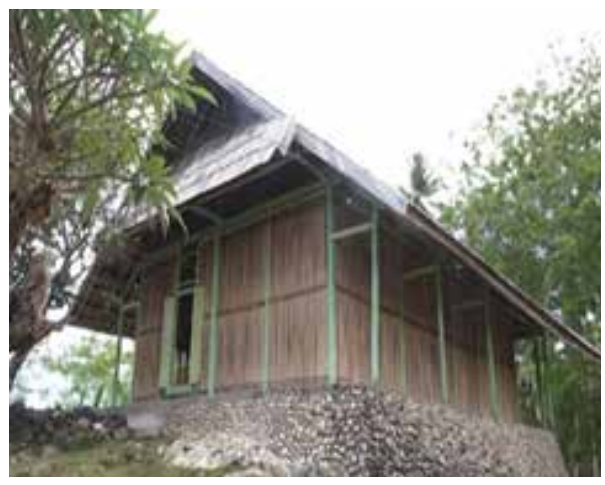

Gambar 2. Majid Wawoangi

Masjid ini dinamakan sesuai dengan nama desa setempat, Wawoangi. Lokasinya strategis berada di puncak bukit di antara Pegunungan
Buton Selatan. Dari masjid, terlihat panorama perairan Laut Banda sejauh mata memandang. Arsitektur masjid juga sangat sederhana, tidak seperti masjid pada umumnya yang dilengkapi kubah, bangunannya pun unik, terbuat dari bambu-bambu lurus berukuran kecil yang disusun sedemikian rupa.

Dari jenis-jenis pariwisata yang ditawarkan oleh Desa Wawoangi, hanya memfokuskan dua jenis objek wisata. Pengembangan produk unggulan desa sebagai program yang harus di jalankan, selain pertanian, perikanan, destinasi wisata merupakan salah satu sektor kekuatan untuk perekonomian desa. Desa dapat mengembangkan potensi pariwisatanya sebagai produk unggulan. Di dalam dunia kepariwisataan sekarang terdapat kecenderungan untuk mengolah potensi daerah. Kegiatan pengabdian kepada masyarakat (PKM) ini dilaksanakan oleh dosen dan mahasiwa Program Studi Ilmu Pemerintahan Fakultas Ilmu Sosial dan Ilmu Politik Universitas Muhammadiyah Buton. Kegiatan pengabdian ini tidak hanya sebagai perwujudan tanggung jawab dosen dalam hal tridharma perguruan tinggi yang dilaksanakan rutin setiap tahun pada masyarakat, melainkan juga sebagai sebuah kegiatan yang memberikan pengalaman kepada mahasiswa untuk belajar dan menerapkan keterampilan sesuai bidang keahlian yang dipelajari untuk diterapkan kepada masyarakat. Kegiatan ini tentunya akan menambah wawasan sekaligus melengkapi keterampilan dosen dan mahasiswa.

Kegiatan PKM ini diselenggarakan di Desa Wawoangi Kecamatan Sampolawa Kabupaten 
Buton Selatan. Masalah yang dihadapi mitra adalah Kurangnya wawasan dan kesadaran masyarakat lokal akan pentingnya pembangunan di bidang kepariwisataan.

Tujuan dari PKM ini dilaksanakan ialah untuk memberikan pendampingan pembinaan pengelolaan pariwisata dan arahan pengembangan pariwisata. Adapun output yang menjadi target dalam pengabdian ini adalah Kepala Desa, Perangkat Desa, Tokoh Masyarakat, dan masyarakat desa Wawoangi mempunyai keterampilan dalam mengelolaan pariwisata dan arahan pengembangan pariwisata.

\section{METODE PENELITIAN}

Pengabdian masyarakat ini dilaksanakan melalui pendekatan modal sosial, sebab hal ini lebih mudah ditemukan dalam masyarakat yang lebih menonjol dalam ikatan budaya, kekerabatan, dan lingkungan. Dengan begitu, pendekatan modal sosial memungkinkan adanya ikatan timbal balik dari dan kepada masyarakat lokal tersebut. Modal sosial sebagai perekat sosial (social glue) pada komunitas masyarakat. Oleh karena itu, modal sosial tersebut akan sangat ditentukan sebagai akumulasi dari beragam tipe dari aspek sosial, psikologi, budaya, kelembagaan, dan aset yang tidak terlihat (intangible) yang mempengaruhi perilaku kerjasama (Arya Maulana Wijaya et al., 2019).

Dengan deskripsi modal sosial seperti di atas, pendekatan seperti itu dapat dijadikan salah satu sarana untuk memberikan pendampingan pembinaan pengelolaan pariwisata dan arahan pengembangan pariwisata kepada pemerintah desa dan masayarakat Desa Wawoangi. Melalui, kondisi masyarakat Desa Wawoangi yang masih memegang erat kehidupan dan pengalaman budaya, serta kehidupan gotong royong masyarakatnya. Maka, pendekatan budaya dan komunitas memungkinkan adanya kolaborasi antara input kebijakan.

\section{HASIL DAN PEMBAHASAN}

Potensi objek wisata Desa Wawoangi memiliki daya tarik wisata yang hingga saat ini belum dikembangkan. Potensi wisata di Desa Wawoangi secara garis besar adalah wisata alam. Potensi wisata alam terdiri dari beberapa potensi objek wisata yaitu Pantai Lapoili Wisata Jembatan Lingkar dan Wisata Religi yaitu Masjid tua Wawoangi.

Kekayaan potensi wisata Desa Wawoangi perlu untuk diarah-kembangkan supaya dapat mendukung pariwisata berkelanjutan. Rekomendasi yang dapat diberikan untuk mengembangkan potensi wisata di Desa Wawoangi diarahkan berdasarkan kondisi Desa yang statusnya dijadikan sebagai desa wisata, namun kondisi ini tidaklah mudah. Hal tersebut harus ditunjukkan dengan pengelolaan dan Pengembangan pariwisata, padahal Desa Wawoangi memiliki potensi wisata yang cukup menarik.

Dengan dikelolanya objek wisata di Desa, ini akan mendorong laju perekonomian rakyat, karena dengan adanya tujuan wisata di desa akan mampu mempromosikan semua sektorsektor ekonomi yang ada di desa, baik itu dari kerajinan, pertaanian, dan budaya. 
Tabel 1. Tahapan Kegiatan Pengabdian

\begin{tabular}{|l|l|l|l|}
\hline No & Tahapan Kegiatan & $\begin{array}{l}\text { Metode yang } \\
\text { Digunakan }\end{array}$ & Keterangan \\
\hline 1 & Survei dan Penetapan Wilayah Mitra & $\begin{array}{l}\text { Pertemuan dan } \\
\text { diskusi }\end{array}$ & $\begin{array}{l}\text { Tim PKM dan Kepala } \\
\text { Desa }\end{array}$ \\
\hline 2 & $\begin{array}{l}\text { Pelaksanaan Kegiatan Penyampaian Materi } \\
\text { Tentang Pariwisata Menjadi Kekuatan Baru } \\
\text { Ekonomi Desa }\end{array}$ & $\begin{array}{l}\text { Pertemuan, } \\
\text { Ceramah, dan } \\
\text { diskusi }\end{array}$ & $\begin{array}{l}\text { Tim PKM, Kepala Desa, } \\
\text { Aparatur Perangkat desa, } \\
\text { Tokoh Masyarakat, dan } \\
\text { Masyarakat }\end{array}$ \\
\hline 3 & $\begin{array}{l}\text { Pendampingan Pengembangan Obyek } \\
\text { Wisata }\end{array}$ & $\begin{array}{l}\text { Mendampingi } \\
\text { dalam } \\
\text { Pengembangan } \\
\text { Obyek Wisata }\end{array}$ & $\begin{array}{l}\text { Tim PKM, Kepala Desa, } \\
\text { Aparatur perangkat desa, } \\
\text { danTokoh Masyarakat }\end{array}$ \\
\hline
\end{tabular}

Penjelasan Tahapan Kegiatan Pengabdian PKM dan hasil akan dijelaskan dalam sub bab selanjutnya.

\section{Survey dan Penetapan Wilayah Mitra}

Tujuan Umum melakukan Survey lapangan adalah untuk mengamati secara langsung lokasi wilayah mitra. Kegiatan pengamatan dilakukan guna menggali dan mengumpulkan data yang diperlukan bagi topik pembahasan guna pengembangan wawasan dan peningkatan kinerja bagi para peserta PKM. Tujuan survey lapangan adalah agar memahami tentang pengumpulan data/informasi, dapat mengetahui cara mengumpulkan data/informasi. Survei lapangan dilakukan secara kelompok.
Pelaksanaan Kegiatan Penyampaian Materi Tentang Pariwisata Menjadi Kekuatan Baru Ekonomi Desa

Tahap Penyampaian Materi Tentang Pariwisata Menjadi Kekuatan Baru Ekonomi Desa, dilaksanakan di balai pertemuan Desa Wawoangi, pertemuan dihadiri oleh kepala desa, aparatur desa tokoh-tokoh masyarakat, dan masyarakat Desa Wawoangi.

Kegiatan ini memberikan pemahaman mengenai Pengelolaan pariwisata berbasis komunitas merupakan suatu alat pembangunan dalam masyarakat guna meningkatkan peran masyarakat agar berpartisipasi aktif untuk mengelola pariwisata dan terlibat
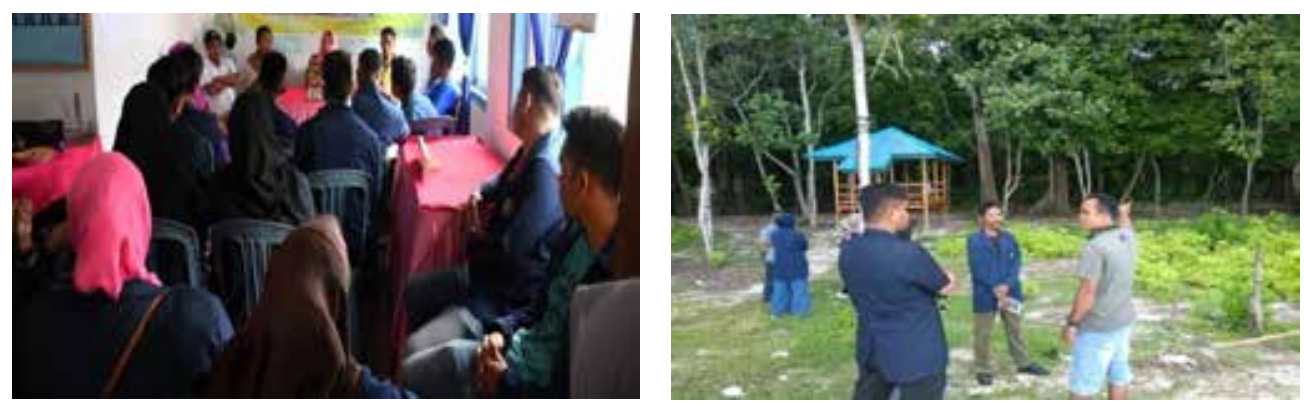

Gambar 3. Survey dan Penetapan Wilayah Mitra 

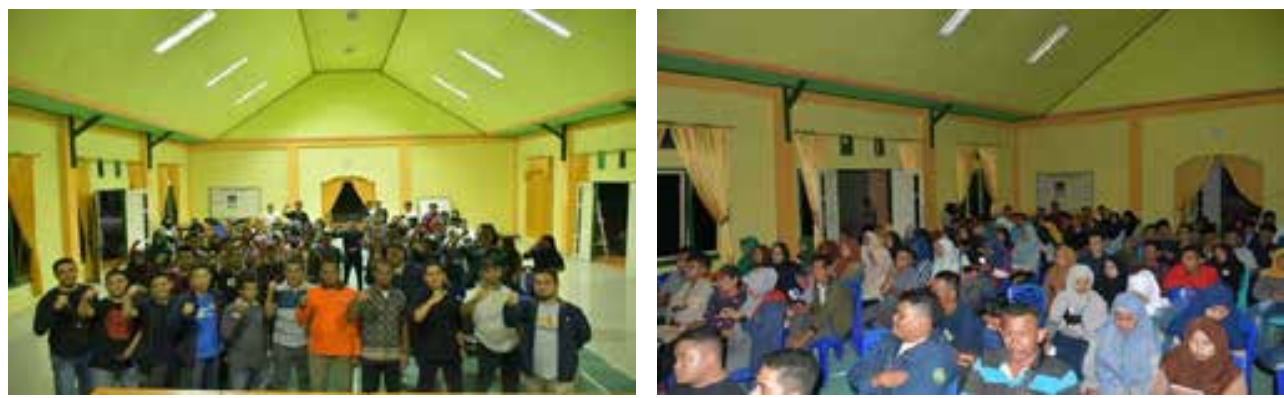

Gambar 4. Penyampaian Materi Pariwisata Menjadi Kekuatan Baru Ekonomi Desa

secara penuh dalam pengelolaan tersebut. Penilaian pengelolaan pariwisata berbasis komunitas mengacu pada beberapa indikator yang menjadi dasar untuk mengetahui pengelolaan pariwisata berbasis komunitas, yaitu pengelolaan atraksi wisata, fasilitas, aksesibilitas, promosi, kemitraan, pemberdayaan masyarakat serta kondisi alam, sosial, ekonomi, dan budaya.

\section{Pendampingan}

Setelah dilaksanakannya penyampaian materi dilanjutkan dengan metode pendampingan yang mana kegiatan ini memberi penjelasan tentang bagaimana meningkatkan pengunjung untuk berwisata di Desa Wawoangi. Penyediaan media promosi harus dilakukan sebagai pengenal kawasan wisata di Desa Waowangi ke masyarakat luar, pengelolaan dari masyarakat setempat agar ikut berperan aktif dalam pengembangan kawasan desa wisata, dan kebijakan pemerintah dalam mengontrol pengembangan kawasan desa wisata di Desa Wawoangi.

Setelah itu bersama-sama mencari solusi rencana tindak lanjut dalam menentukan berapa biaya penyediaan sarana dan prasana yang harus disiapkan di wilayah objek wisata, seperti tong sampah, membuat WC umum, dan gazebo ini dilakukan secara gotong royong yang telah disediakan oleh pemerintah agar layak untuk digunakan bagi pengunjung.

\section{KESIMPULAN}

Pengelolaan pariwisata di Desa Wawoangi masih kurang optimal. Terdapat Beberapa aspek, terutama Pengembangan sumberdaya manusia yang perlu diarah-kembangkan untuk mendukung pengembangan pariwisata di Desa Wawoangi.

Program pengabdian masyarakat ini menyimpulkan bahwa peran modal sosial dapat digunakan untuk masyarakat dalam bentuk pengetahuan lokal, yang kemudian dapat dimanfaatkan sebagai sarana pendampingan, pembinaan, pengelolaan pariwisata, dan arahan pengembangan objek wiata kepada pemerintah desa dan masayarakat Desa Waowangi. Proses meningkatkan pengetahuan masyarakat dalam pengembangan pariwisata dilaksanakan melalui: survei lokasi, penyampaian materi tentang pariwisata menjadi kekuatan baru ekonomi desa, pendampingan dan tindak lanjut penyediaan sarana dan prasana yang harus disiapkan di area obyek wisata untuk menarik wisatawan. 


\section{DAFTAR PUSTAKA}

Arya Maulana Wijaya, A., Sadat, A., Azhar Sa, L., Suherman, A., Fajar Maulana, H., \& Rizal Ardiansah Putra, M. (2019). Pemanfaatan Modal Sosial Dalam Penguatan Program Desa Tangguh Bencana. Jurnal Pengabdian Kepada Masyarakat MEMBANGUN NEGERI, 2(1), 1-13.

Listriyana, A., \& Pahlewi, A. D. (2019). INTEGRITAS : Jurnal Pengabdian INTEGRITAS : Jurnal Pengabdian. 3(1), 42-54.

Out, H., Kuliah, M., Resort, C., Pengembangan, S., \& Pengelolaan, D. A. N. (2010). Konsep pengembangan kawasan desa wisata 1. 1-36.
Sefira Ryalita Primadany, Mardiyono, $R$. (2013). Analisis Strategi Pengembangan Pariwisata Daerah (Studi Pada Dinas Kebudayaan Dan Pariwisata Daerah Kabupaten Nganjuk). Jurnal Administrasi Publik Mahasiswa Universitas Brawijaya, 1(4), 135-143. Zakaria, F., \& Suprihardjo, D. (2014). Konsep Pengembangan Kawasan Desa Wisata di Desa Bandungan Kecamatan Pakong Kabupaten Pamekasan. Teknik Pomits, 3(2), C245-C249. https://doi.org/23373520 